\title{
OPTIMALISASI PERAN SERTA ULAMA DALAM DERADIKALISASI AGAMA
}

\author{
Oleh: \\ Thaufiq Hidayat \\ UIN Imam Bonjol Padang \\ thaufiqhidayat7@gmail.com
}

\begin{abstract}
Various acts of radicalism, which brought several disadvantages and anxieties to Indonesia's peace, have captured the attention of various circles. The act of radicalism that follows violence, threats and even murder becomes a separate motive that contributes to the problem of religious affairs, especially Islam. So far a number radical actions has been carried out by certain Muslims and this has been falsely taken to label Islam as a violent religion. Therefore, it is necessary to held deradicalization programs aimed particularly at religious leaders among society. This act counts as the antithesis of violent radicalism.This study aims to illustrate the steps and actions that must be taken by scholars to alleviate the problem of radicalism. This study used description method. The deradicalization programs begin with the socialization of the negative effects of radicalism held by the government agency for countering terrorism (BNPT) to religious leaders, then the leaders preach it through various media.
\end{abstract}

Keywords: Optimalsasi, Peran, Ulama, Deradikalisasi, Agama

\section{A. PENDAHULUAN}

Sejumlah aksi radikalisme berujung terorisme akhir-akhir ini menyentak Indonesia dari mimpi indahnya. Negeri yang dulu dikenal aman, damai, dan menjujung tinggi nilai religiusitas, moral dan etika, kini menjelma menjadi bangsa yang dicekam ancaman dan ketakutan. Salah satu aksi kekerasan itu adalah drama teror oleh sekelompok orang bersenjata yang tergabung dalam jaringan teroris Bahrun Naim, di kawasan Thamrin jantung ibu kota, pertengahan Januari 2016 lalu (http://www.antaranews.com).

Tindakan seperti itu tidak hanya menimbulkan korban dan kecemasan secara umum, tetapi tidak kalah pentingnya adalah sangat merugikan Islam. Karena dari berbagai data yang tidak terbantahkan memang banyak tindakan radikal dilakukan oleh orang Islam sehingga Islam terseret dilabeli dan dikonotasikan sebagai agama kekerasan. Lantaran itulah menjadi tugas penting bagi umat Islam 
khususnya elit muslim dalam hal ini ulama, ikut serta bersama pemerintah dan unsur masyarakat lainnya untuk mencegah radikalisme yang sangat merugikan dan mencoreng citra agama Islam.

Dalam mencegah tumbuh dan berkembangnya radikalisme pemerintah telah mencanangkan gerakan deradikalisasi sebagai upaya untuk mencegah paham radikal. Ulama sebagai panutan umat harus berperan aktif dan tidak boleh tinggal diam karena masalah ini merupakan kepentingan agama Islam. Sesuai dengan fungsi dan tugasnya ulama harus berperan dalam mencegah radikalisme bahkan merupakan bagian dari tanggung jawabnya sebagai pimpinan umat. Gagasan itulah yang menjadi substansi tulisan yang ada di hadapan pembaca ini. Apa yang mestinya dilakukan ulama dan bagaimana cara melakukannya akan penulis gali lebih lanjut.

\section{B. METODE PENELITIAN}

Penelitian ini adalah riset kepustakaan (library research) yakni riset yang referensinya memakai literatur (kepustakaan) baik berbentuk catatan, buku, atau laporan hasil riset dari peneliti sebelumnya. Pertama-pertama yang dilakukan ialah menghimpun beberapa referensi awal berbentuk buku dan dokumentasi internet yang terkait dengan persoalan, selanjutnya dikomparasikan, serta diambil satu simpulan berkaitan dengan kesamaan dan ketidaksamaan penuturannya.

Data yang didapat dari penggalian pada beberapa sumber data akan diproses lewat beberapa tahapan seperti berikut ; Pertama, melaksanakan proses editing. Untuk step ini, pemilihan serta penyeleksian pada data yang berkaitan dengan objek analisis yang dilaksanakan dengan tepat. Kedua, cara yang dilakukan setelah itu lakukan proses organizing, yakni ; mengontrol serta memproses data yang berkaitan dengan objek riset hingga hasilkan bahan untuk jadi rumusan gambaran. Data data tersebut kemudian dipaparkan dan dianalisis dengan metode deskripsi dan interpretasi.

\section{PEMBAHASAN}

\section{Potret Radikalisme Agama Di Indonesia}

Indonesia selaku negara multi etnis dan agama masih menghadapi persoalan intoleransi dan radikalisme. Kerawanan intoleransi di Indonesia menjadi temuan utama survei nasioanal bertajuk "Potensi Intoleransi dan Radikalisme Sosial Keagamaan di Kalangan Muslim Indonesia" yang digelar Wahid Foundation bekerja sama dengan Lembaga Survei Indonesia (LSI) di Rancamaya, Bogor (Detik.com tanggal 1/8/2016). Paparan hasil survei tersebut bertujuan untuk memberikan masukan kepada Pemerintah dalam menangani persoalan intoleransi dan radikalisme.

Hasil survei yang dilakukan oleh Wahid Foundation itu menemukan sejumlah data yang mengkhawatirkan. Dari total 1.520 responden sebanyak 59,9 persen memiliki kelompok yang dibenci. Kelompok yang dibenci meliputi mereka yang berlatarbelakang agama nonmuslim, kelompok Tionghoa, 
komunis, dan lainnya. Dari sisi radikalisme sebanyak 72 persen umat Islam Indonesia menolak untuk berbuat radikal seperti melakukan penyerangan terhadap rumah ibadah pemeluk agama lain atau melakukan Sweeping tempat yang dianggap bertentangan dengan syariat Islam. Dan hanya sebanyak 7,7 persen yang bersedia melakukan tindakan radikal bila ada kesempatan dan sebanyak 0,4 persen justru pernah melakukan tindakan radikal. Namun Yenny Wahid, Direktur Wahid Foundation, mengingatkan meski hanya sebesar 7,7 persen, persentase tersebut menjadi proyeksi dari 150 juta umat Islam Indonesia.

Hasil survei tersebut apabila dihubungkan dengan kejadian terorisme yang telah terjadi di Indonesia dapat kita runut dari tahun 2000 sampai 2016 lalu akan menjadi singkron. Setelah era reformasi dimulai, Indonesia sudah mengalami aksi terorisme secara beruntun dari tahun 2002-2005. Sebut saja ledakan bom di Bali pada tahun 2002 disusul Hotel J.W Mariot tahun selanjutnya, bahkan Kedutaan Australia di Jakarta tidak luput dari serangan teroris dan diakhiri dengan serangan di Bali untuk kedua kalinya pada tahun 2005 (Rhosyid, 2016:3).

Menurut catatan Rhosyid dalam skripsinya "Terorisme dalam Bingkai Pemberitaan Media Massa" aksi terorisme berlanjut ke tahun 2010-2011 dengan mengubah sasarannya dari korban yang mempunyai simbol kafir ke polisi sebagai sasaran. Misalnya, bom bunuh diri di masjid Mapolres Cirebon pada 11 April 20011. Saat pengamanan lebaran September 2012 pun tidak lepas dari gangguan teroris seperti yang terjadi di Solo dengan cara penembakan dan pelemparan granat ke beberapa pos polisi.

Aksi teror yang masih segar dalam ingatan adalah peristiwa bom Thamrin pertengahan Januari 2016 (http://www.antaranews.com).

Bagaimana drama teror yang dipertontonkan oleh sejumlah orang bersenjata yang berlarian di kawasan Thamrin meledakkan pos polisi dan menembakkan pistol ke kerumunan orang yang menyaksikan pos yang telah diledakkannya. Sungguh mengiris hati, akibat yang ditimbulkan oleh serangkaian kejadian terorisme di Indonesia. Ratusan jiwa tewas dan lebih banyak lagi korban luka di Indonesia akibat aksi terorisme.

2. Dari Radikalisme ke Deradikalisasi

Sebelum lebih jauh membahas radikalisme adalah lebih baik mengetahui terlebih dahulu pengertian radikalisme tersebut. Secara bahasa, radikalisme, menurut Rodin dalam tulisannya "Islam dan Radikalisme", berasal dari bahasa latin "radix" yang berarti akar (2016:34). Sedangkan Kamus Besar Bahasa Indonesia (2009:400) mengartikan radikalisme sebagai paham yang menginginkan perubahan sosial dan politik dengan cara kekerasan. Jadi, secara sederhana radikalisme dapat diartikan paham yang cenderung menggunakan kekerasan untuk mencapai tujuan.

Munip dalam tulisannya "Menangkal Radikalisme Agama di 
Sekolah" membedakan radikalisme ke dalam dua level, yaitu level pemikiran dan aksi (2012:162). Pada level pemikiran, radikalisme masih berupa wacana, konsep dan gagasan yang masih diperbincangkan yang intinya mendukung penggunaan caracara kekerasan untuk mencapai tujuan. Adapun pada level aksi atau tindakan, radikalisme bisa berada pada ranah sosial-politik dan agama. Pada ranah politik, paham ini tercermin dari adanya tindakan memaksakan pendapat dengan cara yang inskonstitusional, bahkan bisa berupa tindakan mobilisasi massa untuk kepentingan politik dan berujung pada konflik sosial.

Dalam bidang keagamaan, fenomena radikalisme agama tercermin dari tindakan destruktif-anarkis atas nama agama dari sekelompok orang terhadap kelompok pemeluk agama lain (eksternal) atau kelompok seagama (internal) yang berbeda dan dianggap sesat. Termasuk dalam tindakan radikalisme agama adalah aktifitas untuk memaksakan pendapat, keinginan, dan cita-cita keagamaan dengan jalan kekerasan. Radikalisme agama bisa menjangkiti semua pemeluk agama, tidak terkecuali di kalangan pemeluk Islam.

Faktor penyebab radikalisme keagamaan terutama agama Islam, menurut Azyumardi Azra sebagaimana dikutip Munip (2012:162), adalah pemahaman keagamaan yang literal, sepotong terhadap ayat-ayat al-Quran; bacaan yang salah terhadap sejarah Islam yang dikombinasikan idealisasi berlebihan terhadap Islam pada masa tertentu; dan deprivasi politik, sosial dan ekonomi yang masih bertahan dalam masyarakat. Pernyataan Azra di atas sejalan dengan pendapat Yusuf Qardhawi bahwa penyebab utama dari paham radikal adalah memahami nash secara tekstual (2004:63).

Adapun ciri-ciri kelompok radikal menurut Masduqi (2013:3) antara lain pertama, sering mengklaim kebenaran tunggal dan manyesatkan kelompok lain yang tak sependapat. Kedua, radikalisme mempersulit agama Islam yang sejatinya samhah (ringan) dengan menganggap ibadah sunnah seakan-akan wajib dan makruh seakan-akan haram. Ketiga, kelompok radikal kebanyakan berlebihan dalam beragama yang tidak pada tempatnya. Keempat, kasar dalam berinteraksi, keras dalam berbicara dan emosional dalam berdakwah. Kelima, kelompok radikal mudah berburuk sangka kepada orang lain di luar golongannya. Dan keenam, mudah mengkafirkan orang lain yang berbeda pendapat.

Tumbuh suburnya paham radikal yang mengatasnamakan agama yang kemudian naik kelas menjadi teroris dan menghancurkan hidup dan kehidupan serta memporakporandakan tatanan dan tuntunan beragama, bermasyarakat dan bernegara, menjadi sebab pemerintah mengambil sikap untuk melakukan gerakan deradikalisasi, sebagaimana dikemukakan oleh Prof. Irfan Idris dalam situs damailahindonesiaku.com. Istilah deradikalisasi merupakan tindak lanjut untuk menurunkan paham radikal menghancurkan ke arah yang lebih okomodatif dan akulturatif. 
Irfan Idris mengartikan deradikalisasi dengan upaya menurunkan paham radikal dari kecenderungan memaksakan kehendak, keinginan menghakimi orang yang berbeda dengan mereka, keinginan keras merubah negara bangsa menjadi negara agama dengan menghalalkan segala macam cara, kebiasaan menggunakan kekerasan dan anarkisme dalam mewujudkan keinginan, kecenderungan bersikap eklsusif dan berlebihan dalam beragama, hasrat birahi menghalalkan darah orang lain dan seolah mereka hidup di tengah rimba manusia yang menjadi lawan Tuhan (2017:17).

Lebih lanjut, Irfan Idris dalam bukunya Membumikan Deradikalisasi menyampaikan program deradikalisasi yang dilakukan oleh pemerintah melalui Badan Nasional Penanggulangan Terorisme (BNPT) tidak akan dapat mencapai hasil yang optimal tanpa melibatkan berbagai pihak mulai dari kementrian dan lembaga, organisasi kemasyarakatan, tokoh agama, tokoh masyarakat serta tokoh adat, tokoh pendidik, tokoh pemuda dan tokoh perempuan hingga mengajak mantan teroris, keluarga dan jaringannya yang sudah sadar dan kembali ke tengah masyarakat dalam pengakuan Negara Kesatuan Republik Indonesia (NKRI) (2017:19).

3. Peran Strategis Ulama dalam Deradikalisasi

$\begin{array}{ccr}\text { Ulama } & \text { sebagai } & \text { sebuah } \\ \text { institusi } & \text { sosial-keagamaan }\end{array}$ memainkan peran penting terutama dalam masyarakat muslim yang masih menganut budaya paternalistik dan memelihara pola kepemimpinan tradisonal patron-client. Ulama dalam Kamus Besar Bahasa Indonesia (KBBI) berarti orang yang ahli dalam pengetahuan Agama Islam (2009:210). Namun dalam pengertian yang lebih menyeluruh ialah orang yang tidak hanya mempunyai pengetahuan tentang ayat-ayat Allah tetapi lebih dari itu juga berpengetahuan luas tentang fenomena alam disebut "ulama"(Shihab, 2007:611).

Menurut Qonita (2008:4), secara normatif peran profetik ulama bertumpu pada spirit teologis sebagai warasat al-anbiya, pewaris para Nabi. Mereka diidealisasi sebagai suluh penerang di tengah gelapnya kehidupan, pancuran ilmu yang terus mencurah di tengah kebodohan umat, pengawal moralitas di tengah dekadensi yang menggila, peneguh kebenaran dan keadilan di tengah dehumanisasi sistemik yang tak sudah-sudah, pencipta damai, penjaga kerukunan, penyubur cinta, penebar rahmat Tuhan bagi seluruh alam (rahmatan lil-alamin).

Ulama di luar peran normatifnya sebagai pewaris Nabi juga merupakan golongan sosial yang telah menjadi bagian dari struktur sosial masyarakat. Di mana ulama memainkan fungsinya dalam status dan peran. Posisi, kedudukan dan peran ulama merupakan sesuatu yang unik dan khas. Sebagai contoh dapat dilihat kedudukan dan peranan ulama pada masyarakat Banten. Ulama berperan sebagai guru mentransfer ilmu kepada masyarakat secara terbuka. Seiring waktu, berdasarkan kedudukan ulama tersebut maka masyarakat Banten begitu menghormati ulama, selain juga 
menghormati orang tua dan guru. Wejangan dari ulama mereka pahami serta lakukan, dan merupakan hal yang tabu untuk dibantah (http://dewantara.id).

Pada era kekuasaan pemerintah militer Jepang, terjadi perlakuan yang berbeda kepada ulama apabila dibandingkan dengan pemerintah kolonial Belanda. Menurut Ahmad Muttaqin dalam http://dewantara.id perlakuan yang berbeda yaitu melalui pengangkatan ulama sebagai kepanjangan tangan pemerintah militer Jepang dalam rangka memobilisasi rakyat demi mempertahankan kepulauan Indonesia dari serangan sekutu. Pemerintah militer Jepang juga mempercayai tokoh ulama untuk melatih dan bertanggungjawab terhadap pembinaan para pemuda, khususnya Pembela Tanah Air (PETA). Jabatan tertinggi yang diberikan kepada tokoh ulama adalah daidancho yang mengepalai satu batalyon yang berjumlah sekitar seribu orang. "Daidancho" tersebut adalah KH. Syam'un, pemimpin pesantren Al-Khairiyah di Cilegon. Ketokohan ulama dalam kehidupan agama dan sosial inilah yang menjadi peran strategis untuk menyampaikan Islam yang moderat dan menjauhkan umat dari paham radikal.

\section{Optimalisasi Peran Serta} Ulama: dari Fatwa ke Mimbar

Untuk mengetahui apa peran ulama dan pencerahan apa yang telah mereka lakukan terhadap masyarakat, antara lain dapat dilakukan dengan mengadakan survei terhadap masyarakat (umat). Sehubungan dengan itu, penulis telah mengadakan survei untuk mengetahui apa saja biasanya topik-topik ceramah yang diberikan oleh ulama saat memberikan ceramah di mesjid atau mushala. Hasil survei yang penulis lakukan pada tanggal 21 April 2017 di sejumlah jamaah mesjid di Kota Padang mengenai topik ceramah yang biasa diberikan ulama, ternyata pembicaraan mengenai ancaman paham radikal sangat jarang diberikan. Dari 50 responden, 15 orang di antaranya menyatakan bahwa topik tentang ancaman paham radikal hanya kadang-kadang saja disampaikan ulama, 28 orang menyatakan sangat jarang dan 7 orang menyatakan tidak pernah sama sekali ada ceramah yang membicarakan mengenai ancaman paham radikal. Data ini mencerminkan fakta bahwa dakwah Islam yang disampaikan ulama sangat minim dalam memberikan kontribusi mengenai pemahaman tentang masalah radikalisme.

Dari data yang penulis ungkap di atas kontribusi ulama harus menjadi perhatian, sangat kurangnya ceramah mengenai radikalisme mencerminkan kurangnya pemahaman atau justru kurangnya kepedulian mereka mengenai ancaman radikalisme. Irfan Idris dalam bukunya Membumikan Deradikalisasi lebih spesifik memberikan istilah kondisi ini dengan "kelalaian ulama", yaitu kondisi di mana sikap ulama tidak lagi peduli terhadap persatuan dan kesatuan di bawah bentuk masyarakat yang plural, berbeda bangsa, agama, suku, bahasa dan tradisi (2017:72). Melihat kondisi demikian, maka peranan ulama sangat diperlukan 
untuk membantu menciptakan kedamaian dan keamanan dari paham radikalisme.

Adapun langkah yang dilakukan agar peran ulama menjadi optimal dalam mencegah paham radikal sebagai berikut: pertama, sosialisasi pencegahan paham radikal bagi kalangan ulama, pimpinan ormas dan pemuda, pengurus majlis ta'lim, dan guru agama. Berdasarkan hasil survei di atas, selama ini agaknya masih banyak ulama yang belum memahami apa itu paham radikal, bahayanya, kenapa muncul dan apa konsekuensinya bagi Negara Kesatuan Republik Indonesia (NKRI). Bentuk sosialisasi yang penulis maksud adalah mengundang seluruh unsur yang penulis sebutkan di atas dalam satu ruangan untuk mendengarkan materi bahaya radikalisme dan perlu adanya dialog antara penyelenggara sosialisasi dengan undangan yang hadir.

Pemerintah dengan segala lembaga di bawah naungannya, sebut saja Badan Nasional Penanggulan Terorisme (BNPT) bersama Forum Koordinasi Penanggulangan Terorisme (FKPT, khusus berada di daerah), Kepolisian dan Kesbangpol mempunyai berbagai data dan informasi mengenai ancaman radikalisme ini. Maka pemerintah harus didorong untuk melakukan sosialisasi kepada ulama dan bersama-sama nantinya melakukan pencegahan. Begitu juga sebaliknya ulama juga harus mau mempelajari dan mengetahui apa permasalahan umat yang sedang mengancamnya. Dalam hal ini al-Quran dalam surat An-Nahl ayat 43 telah mendorong kita untuk bertanya mengenai suatu masalah yang tidak diketahui kepada orang yang lebih tahu, yang berbunyi:

Artinya: ..Maka bertanyalah kepada orang yang mempunyai pengetahuan jika kamu tidak mengetahui.

Menurut Quraish Shihab (2002:234) walaupun penggalan ayat ini turun dalam konteks tertentu, yakni objek pertanyaan serta siapa yang ditanya tertentu pula, namun karena redaksinya yang bersifat umum, maka ayat ini dapat dipahami pula sebagai perintah bertanya apa saja yang tidak diketahui atau diragukan kebenarannya kepada siapapun yang tahu dan dapat dipercaya. Penafsiran ini mendorong ulama sebagai elit muslim untuk, pertama, menambah pengetahuan mengenai masalah radikalisme dan bertanya kepada yang lebih tahu dalam hal ini pemerintah, agar dapat memunculkan solusi sehingga umat Islam terbebas dari bahaya paham radikal.

Kedua, begitu ulama sudah mengetahui mengenai seluk beluk bahaya radikalisme, maka kewajiban ulama menyampaikan kepada umat. Ulama dituntut berdakwah secara sederhana menyampaikan pesanpesan ilahi kepada umat Islam mengenai bahaya paham radikal. Ulama harus menambah ilmu dan mengkaji lebih dalam apa sebenarnya radikalisme itu dan apa tawaran alQuran untuk menghindarinya. Bisa jadi ulama memperkuat aspek tauhid lalu mengkombinasikan dengan ajaran Islam yang damai agar ajaran tauhid yang diberikan tidak mengenyampingkan agama selain Islam sehingga timbul intoleransi. 
Ada tiga metode dakwah yang penulis coba munculkan kembali ke hadapan pembaca yang nampaknya masih relevan dengan permasalahan yang saat ini dibahas. Sebut saja dakwah secara lisan atau lebih dikenal bentuknya adalah ceramah. Ceramah adalah komunikasi antara penceramah dengan jamaahnya untuk menyampaikan pesan-pesan ilahiah. M. Natsir (1988:164) dalam bukunya Fiqh Dakwah memaparkan bahwa penceramah yang masuk ke dalam daerah yang baru atau menceramahkan hal yang baru harus terlebih dahulu mengetahui kondisi sosial, taraf kemampuan kognitif dan bahasa yang dimengerti oleh jamaah.

Keuntungan metode ceramah ini adalah dapat langsung bertatap muka dengan jamaah sehingga informasi yang disampaikan langsung diterima. Penceramah dapat melihat langung reaksi jamaah saat ceramah diberikan. Penulis mendorong ulama agar ceramah yang diberikan tidak hanya satu arah atau penceramah sebagai center tetapi ceramah dengan cara dialog. Ceramah dengan gaya dialog yaitu ceramah agama ada tanya jawab antara penceramah dengan jamaah. Tentu yang didialogkan adalah seputar bahaya radikalisme dan bagaimana pencegahannya. Ayat al-Quran yang mendasari agar berceramah dengan cara dialog ini dapat ditemukan dalam surat An-Nahl ayat 125:

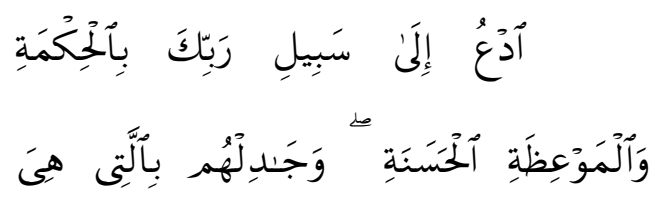

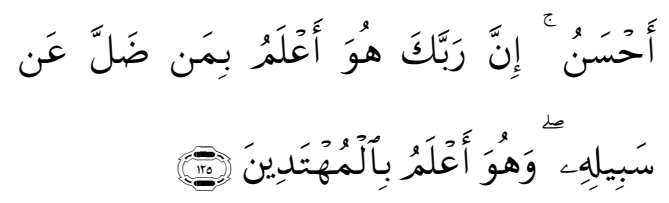

Artinya: Serulah (manusia) kepada jalan Tuhanmu dengan hikmah dan pengajaran yang baik, dan berdebatlah dengan mereka dengan cara yang baik. Sesungguhnya Tuhanmu, Dialah yang lebih mengetahui siapa yang sesat dari jalan-Nya dan Dialah yang lebih mengetahui siapa yang mendapat petunjuk.

Quraish Shihab (2011:774) mengemukakan bahwa ayat ini menjelaskan tiga macam metode dakwah yang harus disesuaikan dengan sasaran dakwah. Terhadap cendikiawan yang memeliki intelektual tingggi diperintahkan menyampaikan dakwah dengan hikmah, yakni berdialog dengan katakata bijak sesuai dengan tingkat kepandaian mereka. Terhadap kaum awam diperintahkan untuk menerapkan mau'izah yakni memberikan nasihat dan perumpamaan yang menyentuh jiwa sesuai dengan taraf pengetahuan mereka yang sederhana. Sedangkan terhadap ahl al-kitab dan penganut agama-agama lain yang diperintahkan menggunakan jidal ahsan,yaitu perdebatan dengan cara yang terbaik, yaitu dengan logika dan retorika yang halus, lepas dari kekerasan dan umpatan.

Selanjutnya adalah dakwah dengan kitabah (tulisan). Keberadaan majalah, surat kabar, tabloid, jurnal, buku serta media internet menguntungkan ulama karena dapat 
digunakan sebagai media untuk menyampaikan pesan-pesan Islami. Dakwah melalui tulisan di media dapat menutupi kelemahan dari dakwah menggunakan ceramah secara oral. Dakwah dengan tulisan dapat memutus jarak, waktu dan dapat dikaji ulang secara mendalam. Dakwah dengan tulisan tidak hanya ada sekarang tetapi jauh sebelum kurun waktu ini telah dimulai. Nabi Muhammad Saw. mencontohkan dakwah dengan tulisan melalui suratsurat yang dikirim kepada penguasa negara Arab pada masanya. Melalui tulisan pula, dua sumber ajaran Islam yakni al-Quran dan sunnah Nabi, serta pemikiran cendikiawan pendahulu dapat dikaji hingga kini. Adapun pemisalan mengenai pentingnya dakwah dengan tulisan ini terdapat dalam surat al-Alaq ayat 45:

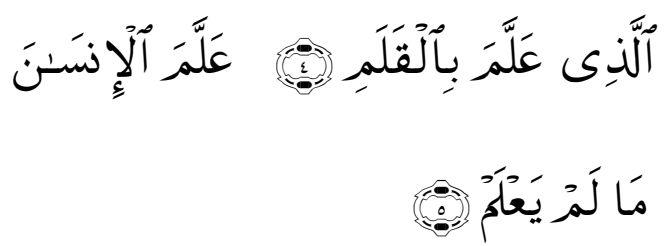

Artinya: Yang mengajar (manusia) dengan pena. Dia mengajarkan manusia apa yang tidak diketahuinya

Menurut Quraish Shihab (2009:392) kata "al-Qalam" terambil dari kata kerja "Qalama" yang berarti pemotong ujung sesuatu. Kata qalam berarti hasil dari pengggunaan alatalat tersebut yakni tulisan. Quraish Shihab menambahkan bahwa ayat 4 dan 5 di atas berarti "Dia (Allah) mengajarkan dengan pena (tulisan) (hal-hal yang telah diketahui manusia sebelumnya) dan Dia mengajarkan manusia (tanpa pena) apa yang belum diketahui sebelumnya. Yang terpenting dari ayat di atas adalah bagaimana Allah SWT. memberitahu umatnya agar memberdayakan potensi diri untuk menulis. Tulisan yang diharapkan adalah tulisan menyuruh kepada kebaikan dan mendatangkan maslahat. Sekarang penyebaran paham radikal melalui berbagai media termasuk media cetak, maka untuk itu ulama dituntut untuk dapat meng-“counter" berbagai tulisan radikal itu dengan tulisan yang memberi pemahaman yang benar.

Dakwah dengan media teknologi adalah tawaran terakhir penulis. Teknologi sangat strategis sebagai media dakwah sebut saja TV, radio dan internet. TV dan radio dengan segala programnya sangat mudah diakses dan ditonton oleh masyarakat luas. Setiap hari masyarakat diberikan tontonan yang baik dan tidak jarang malah membuat masyarakat mengikuti budaya premanisme akibat meniru adegan di TV. Siaran dan program di TV dan radio yang tidak baik harus dapat disaring dan diadakan lawannya. Untuk itu penulis mendorong ulama dengan berbagai organisasi kemasyarakatannya mendirikan stasiun TV dan radio sendiri sebagai lawan dari siaran-siaran yang tidak baik. Ulama dapat membuat program tersendiri untuk pencegahan bahaya radikalisme dan pengkajian tentangnya.

Media internet merupakan media yang sangat digemari remaja saat ini juga tidak terlepas dari ancaman paham radikal. Media sosial yang ada dalam internet, sebut saja facebook dan whatsapps serta tempat menonton 
vidio yaitu youtube, merupakan kawasan bebas dalam internet yang menyampaikan segala macam tulisan, hasil pikiran dan adegan. Untuk itu ulama juga dituntut mampu menggunakan media sosial tersebut dan mampu mengadakan tandingan bagi tulisan-tulisan yang mengarah ke radikal dan menyampaikan pesanpesan Islam yang moderat.

Ulama juga dapat membuat grup di facebook dan whatsaps dengan mengisi tulisan-tulisan yang mencerminkan Islam ramatan lil alamin. Ajakan di facebook dan whatsaps itu dapat disebarkan ke seluruh anggota di grup dan tidak menutup kemungkinan juga disebarkan ke luar grup sehingga semakin banyak orang yang membaca dakwah melalui media internet itu. Juga tidak kalah menariknya adalah dakwah dengan menayangkan vidio ceramah di youtube. Sebut saja ustad Abdul Shomad Lc. merupakan contoh ulama yang mampu memberdayakan internet untuk dakwah. Untuk itu penulis sangat mendorong ulama-

\section{Daftar Kepustakaan}

Idris, Irfan. 2017. Membumikan Deradikalisasi. Jakarta: Daulat Press.

2015. Memahami Esensi

Deradikalisasi.

https://damailahindonesiaku.c om/memahami-deradikalisasi. Diakses tanggal 15 Oktober 2020. ulama yang lain juga melakukan hal demikian.

\section{KESIMPULAN}

Menangkal radikalisme diperlukan peran serta tokoh agama dan masyarakat. Kontribusi ulama, mubaligh, ustad, dan da'i dalam memberikan pengajaran, pemahaman ajaran Islam yang damai, beragama yang moderat, dan Islam rahmatan lil alamin sangat diperlukan dalam menangkal radikalisme. Uraian mengenai pengentasan paham radikalisme bermuara pada tuntutan terhadap ulama untuk memberikan ceramah mengenai bahaya radikalisme. Adapun langkahlangkah penulis berikan mengenai pemecahan masalah ini adalah sosialisasi oleh pemerintah kepada ulama mengenai bahaya paham radikal; ulama mendakwahkan melalui lisan, kitabah, dan yang terakhir melalui teknologi. Tuntutan ini merupakan bentuk tanggung jawab ulama sebagai elit muslim yang berada di garda terdepan ketika Islam dan pemeluknya diancam paham radikal.

Laisa, Emna. 2014. Islam dan Radikalisme. Jurnal Islamuna Vol. 1 no. 1.

Masduqi, Irwan. 2013. Deradikalisasi Pendidikan Islam Berbasis Khazanah Pesantren. Jurnal Pendidikan Islam vol. II no. 1.

Munip, Abdul. 2012. Menangkal Radikalisme Agama di Sekolah. Jurnal Pendidikan Islam vol. 1 no. 2 
Thaufiq. H, Optimalisasi Peran Serta Ulama... 78

.2007. Membumikan

al-Quran. Bandung: Mizan

Pustaka.

Muttaqin, Ahmad. Peran Ulama dan Jawara dalam

Mempertahankan

Kemerdekaan RI di Banten. http://dewantara.id/2017/09/0

1/peran-ulama-dan-jawara.

diakses tanggal 10 Oktober 2020

Natsir, M. 1988. Fiqh Da'wah. TT: Media Dakwah

Rhosyid, Muhammad Imron. 2016. Terorisme dalam Bingkai Pemberitaan Media Massa, Skripsi S1. Yogyakarta: UIN Suka

Rodin, Dede. 2016. Islam dan Radikalisme. Jurnal Addin vol. 10 no. 1

Shihab, Quraish. 2011. Tafsir alMisbah. Jakarta: Lentera Hati 2009. Tafsir alMisbah. Jakarta: Lentera Hati

Qonita, Ulya. 2008. Sikap Politik Kiai dan Implikasinya Terhadap Pilihan Politik Santri Kaliwungan dalam Pilkada Kendal Tahun 2005, Skripsi S1. Semarang: IAIN Semarang.

https.antaranews.com/berita/bomthamrin. Diakses tanggal 12 Oktober 2020

http://nasional.kompas.com $/ \mathrm{read} / 2016 / 08 / 01 / 13363111 / \mathrm{su}$ rvei-wahid-foundation. Diakses tanggal 16 Oktober 2020 